JURNAL

TATA KELOLA DAN AKUNTABILITAS KEUANGAN NEGARA

Volume 6, Number 2, Jul-Dec 2020, 163-177

e-ISSN 2549-452X

p-ISSN 2460-3937

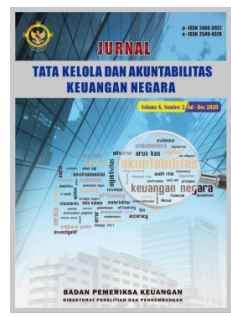

\title{
THE IMPLEMENTATION OF RESTRUCTURING PROGRAM AND ACTIVITIES BASED ON THE MONEY FOLLOW PROGRAM IN REGIONS
}

\author{
Melati Ayuning Pranasari ${ }^{1}$, Suci Emilia Fitri ${ }^{2}$ \\ Research and Development Agency (BPP) Ministry of Home Affairs ${ }^{1,2}$ \\ Jakarta, Indonesia \\ uchy.kemendagri@gmail.com ${ }^{1}$ \\ melatipranasari@gmail.com²
}

\begin{abstract}
The current planning and budgeting paradigm has changed from money follows function into money follows program but this paradigm is considered to not provide clear and concrete benefits. Likewise, the implementation of the money follows program was still problematic, such as program restructuring and problematic activities. Based on these problems, the purpose of this study is to determine the implementation of restructuring programs and activities of local governments and the factors that support and hinder the implementation of restructuring programs and activities in local governments since the enactment of the money follow program. The method used in this study is a descriptive method with a qualitative approach. The results show that programs and activities planned by using the money follow program approach have been implemented in several locus study areas (West Sumatra Province, West Java Province, and Yogyakarta Province). However, the implementation still varies. There are still doubts for the regions in the implementation, especially because it is related to the legal basis. Likewise, there are several inhibiting factors such as human resources, policy substance, implementer behavior, and network interactions. For this reason, the study concludes that it is necessary to make adjustments to the central government policies related to regional development planning guidelines and budget allocation.
\end{abstract}

\section{KEYWORDS:}

Money follow program; money follow function; activity program; budget

DOI: $10.28986 /$ jtaken.v6i2.447 


\section{INTRODUCTION}

Law Number 17 of 2003 concerning State Finances mandates that budget users in preparing planning and budgeting must be based on several criteria. They must be performance-based (performance-based budgeting), medium-term (medium-term expenditure framework), and pay attention to the unified budgeting system. This regulation was also strengthened by the presence of Law Number 25 of 2004 concerning the National Development Planning System. The two regulations show the relationship and consistency between planning, budgeting, implementation, and supervision. This is because Law Number 25 of 2004 ensures that the preparation of a national development strategy must take the funding framework into account.

Besides, the consistency of national development planning is also mandated by the latest regulations such as Law Number 23 of 2014 concerning Local Government. The Law of Local Government requires regions to prepare development planning documents consisting of Regional Medium Term Development Plans (Rencana Pembangunan Jangka Menengah Daerah, RPJMD), Regional LongTerm Development Plans (Rencana Pembangunan Jangka Panjang Daerah, RPJPD) (Zarista \& Ichsan, 2020), and Local Government Work Plans (Rencana Kerja Pemerintah Daerah, RKPD). Regarding those several regulations, coordination, and synchronization between planning and budgeting at the central and regional levels are required. For example, the preparation of RKPD must refer to the Government Work Plan (Rencana Kerja Pemerintah, RKP).

On the other hand, when the coordination and synchronization between planning and budgeting at the central and regional levels were not optimal, the paradigm in planning and budgeting began to change. The prepa- ration of planning and budgeting is no longer oriented towards money follows function, but has to be oriented towards money follows program. This was also a direction from President Joko Widodo in his cabinet, who urged all cabinet ministers to use their spending budgets according to priority programs (Kusuma, 2016).

These reasons were clear because the previous budgeting system still used the money follow function system, in which the budget followed the duties and functions of the line ministries. In 2017, the State budgeting must be oriented to benefits for the people and priority-oriented to achieve national development goals (Analisis Kebijakan, 2019). On the other hand, the shifting of the money follows function paradigm into money follow program aimed at maximizing the achievement of development and government priorities and right on target (Saputri, 2019). Presidential directives automatically require that adjustments not only be made by the ministries/agencies at the central level but also apply to local governments.

The preparation of planning and budgeting by using the money follow function paradigm has been considered problematic. Some of the problems, such as programs and activities along with their performance indicators, are not yet fully used as a means of measuring the effectiveness of achieving development goals. Then spending and performance accountability are also far from efficient. Also, this principle makes programs often arranged based on line items (details of expenditures), not in the form of outputoriented activities. As a result, there is no visible linkage with the expected outcome (Bappenas, 2009). The money follows function paradigm also often raises sectoral egos (Himawan, 2017).

The money follows function paradigm actually has benefits. However, if looked at the 
current reality, many autonomous regions have not been able to implement this concept properly. This can be seen from the fact that regional financial management cannot be utilized optimally due to the lack of ability to carry out their respective functions. Regional financial funds cannot be managed properly, so they must be returned to the state. Not because some of the funds that have been used are sufficient to meet the needs of the region, but rather the lack of clarity of the work units involved in predicting and interpreting what should be included in the budget line and how the funds are allocated. Increasing the amount of the budget without improving leadership qualities and without solving problems (Haliim, 2020).

Several studies related to the paradigm of planning and budgeting, especially those related to the money follow program-based budgeting paradigm have been conducted. For example, research related to the implementation of performance-based budgeting with money follows program concept in planning and budgeting in Padang, West Sumatra conducted by Ningsih, Wirahadi, and Fontanella (2018). Their research found that Padang City Government had implemented performance-based budgeting with the concept of the money follows program in planning and budgeting activities. This can be seen from the establishment of an organizational strategy (vision, mission, goals, and objectives), determination of activities, and evaluation of the performance of the previous period.

The principle of the money follows program has also been implemented in Lampung Province. Saputri (2019) found that the money follows program principle was outlined in Regional Regulation of the Lampung Province Number 27 of 2017 concerning the 2018 Budget Year. However, there are still deficiencies in the implementation of these principles such as the lack of human re- sources and limited regional financial capacity.

So far, research related to the application of the money follows program principle in several regions is still limited. Apart from the two studies above, almost no other similar studies were found. The studies, that are the closest, are related to the effectiveness of the implementation of performance-based budgeting on the performance of regional apparatus in Malang Regency conducted by $\mathrm{Su}-$ harnoko (2019). The results of this study indicate that the implementation is generally quite effective in terms of performance assessment potential, human force potential, and technical ability. The local government has made preparations for the implementation of performance-based budgeting, especially by issuing various technical instructions and the implementation. The results also show that the better the implementation of performance-based budgets, the better the absorption of the budget. This is because, in the budget formulation process which is systemically planned with a performance orientation, the absorption rate of the budget will be neatly scheduled, making it easier for the government to monitor, evaluate, and report information on the progress of the program being implemented.

Therefore, research related to program restructuring and activities based on the money follows program in the regions is very important. This study is also conducted to determine the implementation of restructuring programs and activities in local governments since the enactment of the money follow program-based budgeting and the factors that support and hinder its implementation. The existing studies have not discussed specifically, the factors that affect the implementations of the programs especially in Yogyakarta Province, West Java Province, and West Sumatra Province. Based on those issues, this research will discuss several re- 
lated issues such as the implementation of restructuring programs and activities in local governments in three provinces since the implementation of the money follows program, as well as supporting and inhibiting factors for the implementation of restructuring programs and activities in local governments since the enactment of the program.

\section{RESEARCH METHOD}

This study focuses on the implementation of restructuring programs and activities based on the money follows program in three provinces; Yogyakarta, West Java, and West Sumatra. The locations were selected by purposive sampling, in which these areas were areas with high-performance evaluation scores based on the results of the Regional Government Implementation Performance Evaluation (Evaluasi Kinerja Penyelenggaraan Pemerintahan Daerah, EKPPD) conducted by the Directorate General of Regional Autonomy at the Ministry of Home Affairs in 2016. The study combines descriptive methods with a qualitative approach. This approach is considered appropriate because the variables regarding the restructuring of program activities based on the money follows program are considered to be multidimensional (Alwasilah, 2003).

Various perceptions from various parties involved, as well as various supporting documents related to the policy, were explored. Secondary data collection, in the form of electronic documents and physical documents as well as coverage in the mainstream mass media, was carried out to enrich the analysis. Meanwhile, to obtain perceptions from the various parties involved, in-depth interviews were conducted with various sources from three regions. Resource persons include the Head of the Regional Development Planning Agency (Badan Perencanaan Pembangunan Daerah, Bappeda), the
Head of the Regional Asset and Financial Management Agency, and experts in the field of public policy and regional finance. Data was also obtained through focus group discussions (FGD) with several local governments such as Yogyakarta Province, West Sumatra Province, and several regions considered to have implemented budgeting based on the money follows program such as DKI Jakarta Province, Central Java Province, Bogor City, and Depok City, as well as experts in planning and budgeting.

\section{RESULT AND DISCUSSION}

The money follows program is a budgeting approach that focuses more on programs/ activities that are directly related to national priorities and have a direct impact on society to achieve national development goals (Bappenas, 2016). In its implementation, the principle of money follow program emphasizes several things such as securing allocations to priorities, reallocation of program activities that have been sufficiently emphasized in the previous year, and efficiency of non-priority programs/activities (Bappenas, 2016).

The budgeting paradigm is actually quite effective. This is because budgeting is carried out through three approaches, which are holistic-thematic, integrated, and spatial approach (Lestari, Suryono, \& Domai, 2018). A holistic-thematic approach, emphasizing the achievement of priority targets from work units/other work units, must coordinate with multiple work units. Second, the integrative approach, which emphasizes in development, must be done in an integrated way. Third, the spatial approach, emphasizes infrastructure development, must consider the integration with other infrastructure. Thus, in this paradigm, one priority program can be supported by more than one work unit. This is different from the money follows 
function approach which emphasizes that budget allocation must be based on the function of each unit in government organizations.

The concept of the money follows function aims to build an effective and efficient budgeting concept and maintains fiscal sustainability through efforts to improve quality spending. In the money follows function concept, it does not necessarily divide the budget among all units/organizations equally, but there is still an assessment process for the proposed program/activity to be proposed by each unit/organization. The assessment concerns whether the proposed program/activity is included in the priority process that must be funded or not and how it contributes and impacts on development implementation. Whereas, in the money follows program concept it is emphasized that there is a need for a budgeting approach based on the priority of the program/activity under the objectives set by the government, where the program/activity is said to have a high priority if it provides great benefits to the people (Ningsih, Wirahadi, \& Fontanella, 2018). As in Table 1, it can be seen the differences between the money follow programbased budgeting planning with the money follow function in terms of budget allocation, allocation planning, and budget execution.

\section{Implementation of Restructuring Pro- gram Based On Money Follow Pro- gram}

In the preparation of regional development planning and budgeting, the principle of the money follows program has been used, which is the principle in the Preparation of Regional Revenue and Expenditure Plan (Rencana Anggaran Pendapatan dan Belanja Daerah, RAPBD). In the money follows program, a budgeting approach focuses more on programs/activities that directly relate to national/regional priorities and have a direct impact on society to achieve national development goals (Wasono \& Maulana, 2018). The implementation of the money follow program is seen from the aspects, those are securing allocations to priorities, reallocation of program activities that have been sufficiently emphasized in previous years, and efficiency of non-priority programs/ activities.

West Sumatra, West Java, and Yogyakarta provinces have implemented the money follow program principle in the preparation of RAPBD in their respective regions. Besides,

Table 1. The difference between Money Follow Function and Money Follow Program

\begin{tabular}{|c|c|c|}
\hline Description & Money Follow Function & Money Follow Program \\
\hline Allocation planning & $\begin{array}{l}\text { Starting from identifying the needs of ministries/ } \\
\text { agencies } \\
\text { - Implementation of duty and function } \\
\text { - Priority support }\end{array}$ & $\begin{array}{l}\text { Starting from determining the priority pro- } \\
\text { gram to be lowered to the relevant } \mathrm{K} / \mathrm{L}\end{array}$ \\
\hline Budget Allocation & $\begin{array}{l}\text { Rigid, because of the separation of the organi- } \\
\text { zation with its respective goals }\end{array}$ & $\begin{array}{l}\text { It is easier to conduct because it is aimed at } \\
\text { achieving program goals }\end{array}$ \\
\hline $\begin{array}{l}\text { Budget execu- } \\
\text { tion }\end{array}$ & $\begin{array}{l}\text { - The person in charge is in each unit } \\
\text { - Potentially not integrated with each other } \\
\text { (policies, indications, spatial location and deve- } \\
\text { lopment sequence) }\end{array}$ & $\begin{array}{l}\text { - Policies are easier to integrate because of } \\
\text { the controls are on priority programs } \\
\text { - Can be appointed person in charge of cross- } \\
\text { unit activities. }\end{array}$ \\
\hline
\end{tabular}

Source: Bappenas (2016) 
knowledge related to the principle of the money follows program are varying from region to region. The money follows program policy yet does not have legal force, but the Provinces of West Sumatra, West Java, and Yogyakarta have implemented it. This is because this policy is a direction from the president and an emphasis from both the National Development Planning Agency (Badan Perencanaan Pembangunan Nasional, Bappenas) and the Ministry of Home Affairs so that the local governments apply the money follows program policy in the preparation of planning and budgeting for 2017.

The money follows program is also the basis for performance appraisal which emphasizes quality. Yogyakarta Province, for example, implemented it as the basis of awareness to achieve development targets. The principle of the money follows program is that the budget must be used to carry out useful development programs and become a priority to answer the problems faced. For this reason, Yogyakarta received an award for the success of compiling and presenting the 2016 Financial Statement with the highest standard achievement from the Ministry of Finance of the Republic of Indonesia. The preparation of the RKPD will always be linked to the RKP, wherein the preparation of the 2017 RKP, the government has implemented the principle of the money follows program. This is the basis for the local governments in implementing the money follows program policies in preparing regional development planning and budgeting. In addition, synchronization of planning and budgeting at the central and regional levels must be carried out.

\section{West Sumatra Province}

West Sumatra Province has implemented the preparation of programs and activities based on the money follows program. The results of field observations also indicated that the socialization of the money follows program policy had often been discussed in meetings. In the implementation of the money follows program principle, program proposals are based on regional priority programs contained in the 2016-2021 RPJMD. The procedures for preparing programs, and activities are clearer by referring to program indicators in RPJMD and Regional Government Agency (Organisasi Perangkat Daerah, OPD) strategic plans. Officials from the Research and Development Agency and the Public Works Agency expressed the same thing regarding the program proposal procedure. Besides, program planning is also more effective in terms of time since it is faster. Moreover, the money follows program policy is easier to implement because budgeting is more precise and accurate in the calculation.

The mindset changing is indeed an obstacle for West Sumatra Province. The old mindset is slowly changing itself, and now it is already based on priority programs. One of the difficulties in applying the money follow program approach is synchronizing national and regional priority. In the national priority, there is a food security program, and it is an obligatory affair to support food security which needs support from agriculture, while agriculture is not a mandatory affair but a choice. Thus, the absence of synchronization between national priorities and mandatory functions creates difficulties in budgeting (Matondang, Basri, \& Arfan, 2015).

The implementation of the money follows program policy is also inseparable from the efficiency in the use of resources owned by the regions, namely human resources, assets, and technology. The number of human resources required to implement this policy is still insufficient. This becomes a problem in almost every government agency, although from a quality perspective it is already good. The limited human resource planners make the team have to work harder than before. In 
addition to the limited number of human resources, there are also limited funds to support priority programs.

The facilities and infrastructure are quite good, equipped with several computers and laptops that support the process of entering the e-planning application. However, it is often constrained by the network and internet connection. The implementation of the money follow program policy has utilized technology, namely the use of the e-planning and e-musrenbang Sakatoplan applications for submitting proposals to the central government. The use of these applications still requires human resources for its implementation because applications only help to make planning more transparent and systematic. The West Sumatra provincial government considers that the socialization of program formulation and activities based on the money follows program from the central government currently is still lacking, especially concerning the policy orientation of the central government and the regional planning system. Time constraints and inadequate socialization to the regions are the causes of problematic regional compilation.

\section{West Java Province}

Based on the results of field observations, West Java Province already knows and implements the money follow program policy in the preparation of regional development planning and budgeting documents. Although, there is no legal basis and specific socialization related to the money follow program principle. The leading sector in implementing the money follows program in West Java Province is Bappeda. In this case, Bappeda determines that each activity must be based on a Multi-Party Action Plan for the Implementation of the Package (Rencana Aksi Multipihak Implementasi Pekerjaan), in which several OPD carry out an activity.
The implementation of the money follow program in West Java prioritizes priority programs and the efficiency of non-priority programs. The determination of the regional priority program is based on the vision and mission of the regional head as outlined in the 2013-2018 RPJMD of West Java Province. For regional priority programs, the governor has set priority programs, then each OPD proposes detailed activities based on regional priority programs. Yet, in its implementation, not all OPDs get the same budget. The budget given depends on the proposed programs and activities. The OPD budget will be larger if the proposed programs and activities lead to regional priority programs compare to OPDs that do not implement priority programs. The principle is to secure allocations for priority programs and make efficiency for non-priority programs. The budget is still given for nonpriority activities/routine activities, but the budget is not as big as the regional priority programs.

There are three sub-indicators used to see the linearity of the policy in the implementation of the money follow program policy, those are procedure, time, and implementation (Deda, Karamoy, \& Gamaliel, 2017). The procedure for applying the money follow program principle is to determine priority programs, priority activities, and program activities for regional and crossregional apparatuses. Determining regional priority programs cannot be separated from the national priority programs.

The procedure or mechanism in planning and budgeting based on the money follow program policy in West Java Province is implemented under the mandate of Law Number 25 of 2004 concerning National Development Planning System (Sistem Perencanaan Pembangunan Nasional, Sisrenbangnas) and Local Government Regulation Number 6 of 2009 on Regional Deve- 
lopment Planning System (Sistem Perencanaan Pembangunan Daerah, Sisrenbangda). Meanwhile, budgeting follows the mandate of Law Number 17 of 2003 concerning State Finances, meaning that there has been no change in the mechanism but the approach has changed from the money follow function to the money follows program. All OPD can propose programs and activities according to predetermined pathways/ forums and are discussed through the Community Consultations on Development Planning (Musyawarah Perencanaan Pembangunan, Musrenbang). The proposed programs and activities are verified concerning regional priority programs and budget capacity.

The implementation of money follow program has resulted a clear and concrete activity program. All proposed programs and activities have been directed to priority programs and there is a division of roles in each ministry and agencies. Formulation of programs and activities based on the principle of money follow program clearly will be more effective and efficient because it prioritizes priority objectivity, so that it is clearer and more measurable for achieving development goals. The principle of the money follow program is a new principle and its implementation requires a process because changing mindsets is not easy. In its implementation, all parties feel the impact, especially the OPDs that handle priority programs and the amount of budget allocated to them. They will get benefit greatly and receive a larger portion of the budget and allocation of resources. Therefore, if it is utilized properly, it will have an impact on the achievement of the target program indicators. However, there were several OPDs that experienced regional prioritization by Bappeda which tended to be top-down planning, even though the determination of activities was a proposal from the OPD but could not be separated from the priority program.
The preparation of programs and activities using the money follows program principle requires a shorter period of time. Bappeda stated that because stakeholders have been directed to fit the predetermined priority programs, there will be less debate and discussion will be more effective. The preparation of regional development planning often takes extra time when determining programs and activities. However, by using the money follow program principle, each OPD understands that the direction of program planning and activities has been directed to support priority programs. Thus, OPD that proposes activities outside the regional priorities will receive a small budget, and those that support priority programs will receive a large budget. The same understanding will be able to shorten the time it takes.

Apart from that, there is an efficiency in terms of time, since the use of money follow the program as well as in the preparation of the plan have been using the IT system known as RKPD online. Each proposed program and activity must refer to the area indicators already in the system, and accelerate the process of program and activity input. Utilization of IT in planning preparation cannot drastically reduce the number of human resources required, because offline processes are still needed.

Although the number of activities decreased a lot after the implementation of the money follows program, the budget was not changing in 2017. The amount of budget needed was Rp12,821,231,139,000.00 while in 2018 the budget was Rp15,835,222,613,594.oo. The focus of the program in the money follow program is on priority programs, and to support the priority programs a fairly large budget is needed. This occurs because activities reduced are routine activities with small outputs, where the budget is transferred to support priority programs. The budget available to support priority programs is greatly 
helped by sharing funding through both the government and the private sector, particularly for strategic programs/activities at the national and international levels.

\section{Yogyakarta Province}

Yogyakarta Province also has implemented the principle of the money follow program in the preparation of regional development planning and budgeting. Although it does not have any legal basis related to the money follow program policy, Yogyakarta Province has started in 2015 and fully implemented it in 2016. The regional development planning approach with the regional priority program approach is in line with the RKP.

The implementation of the money follow program in Yogyakarta Province is based on the demand to get good scores for the preparation of the Performance Accountability Report of the Government Agency (Laporan Akuntabilitas Kinerja Instansi Pemerintahan, LAKIP). In line with these demands, Yogyakarta Province strives for measurable performance indicators and good accountability. In performance-based budgeting, performance targets performance measurements, supporting data sources, and measuring tools must be clear. In addition, there is a relationship between vision and mission, goals, performance targets and accountability. Yogyakarta Province initially made changes to planning and budgeting in its regions, and the methods used were in line with the principle/concept of the money follow program.

The difference between the money follow function and the money follow program is that the money follow function is more about the financing function in the organizational structure, where financing is a structure that has been formed to produce. This is because basically the existing functions are structured to be important. Each OPD is an important element and has a performance target, this makes it less focused on development targets. On the positive side it is stable (no fluctuation occurs) because all structures receive a budget. This approach makes it different from the money follows program.

First, the money follows program approach has an impact on institutions (vision-driven organization). The theme for the development in RKP is an important part of the preparation of the RKPD document in Yogyakarta Province. RKPD is formed based on RPJMD and refers to RPJMN. Alignment of regional development programs and activities at the Yogyakarta Province with development priorities at the national level is carried out by referring to RKPD in RPJMN according to the relevant stages.

There are nine priority programs in Yogyakarta Province, and they cannot be balanced because there are several functions that do not work. Implementation of the money follow program and concurrency in law is not appropriate. For example in Yogyakarta Province, the organizational structure still used the old one, then there was a change of authority, where the management of air transportation became the central authority, while the budget was still given to the regional government. The implementation of the money follow program is not that simple, there are several aspects that must be considered, including administrative and institutional aspects. Institutional aspects since the enactment of Government Regulation Number 18 of 2016 concerning Regional Apparatus regulate typology for each OPD, namely typology A to C. If this is linked to the money follow program, many things will not match, therefore the strategy must be prepared and implemented. For Yogyakarta Province, it does not have to apply Government Regulation Number 18 of 2016 since it is a special region. 
The implementation of the money follows program makes clearer and concrete programs and activities. The consequence of implementing the money follow program approach is that many activities are eliminated, especially those that do not support regional priorities. Programs and activities with small outputs have been eliminated. For example FGD activities are replaced by building a "community" that guards a process. Reducing the number of activities or combined several activities is not an easy thing to do. This will indirectly affect people's perceptions because the affordability of speed in development will have a direct impact on society. It requires great effort and energy, also competent human resources, especially for OPDs that carry out regional priorities.

Planning implementation with the money follow program principle in Yogyakarta Province is to secure the allocation of priority development targets and the efficiency of non-priority programs/activities. Planning activities are adjusted to the previously prepared cascading. Proposed programs and activities are based on regional priority programs as stated in the RPJMD (Rosita, 2017). The depth of the program and priority activities each year becomes the governor's direction at the beginning of the preparation of the RKPD. Planning for programs and activities no longer considers the organizational structure up to echelon 4 but becomes a joint program/activity, and the program is implemented jointly with several OPDs for a wider scope.

The planning cascade implemented in the Yogyakarta Province is a derivative of the vision then becomes the mission, then elaborated into the goals and objectives of regional development. Next, this target is derived into regional development programs. This regional development program is a collection of priority programs (the basis of the money follow program) and cannot be separated from the national priority program. These regional priority programs will be the strategic targets, programs (outcome) as well as OPD activities (output) of OPD. The planning cascade in Yogyakarta Province can be seen in Figure 1.

The planning and budgeting mechanism in Yogyakarta Province is adjusted to the cascading that has been prepared. Priority programs are prepared in advance by Bappeda which is an elaboration of the governor's vision and mission, then each OPD proposes activities according to the predetermined priority programs. Concerning budgeting, the largest budget is allocated for priority programs and activities, while the lesser budget is allocated for non-priority programs. After an OPD proposes activities to be combined at Bappeda to prepare a budget, there is a discussion with all OPDs results in a final draft which becomes a mutual agreement.

\section{Supporting and Inhibiting Factors}

Some of the obstacles faced by the regions in its implementation are the absence of a clear legal basis and guidelines regarding the money follow program approach. It makes each region has a different perception (Pranata, Irianto, \& Adib, 2018). Regions also experience difficulties in determining regional priorities, especially if there are changes in regional heads with different visions and missions. In its implementation, the money follows program policy is considered to be easier in arranging activities because the program is predetermined. But according to $\mathrm{OPD}$, the policy seems as if the planning is top-down.

Another obstacle is in determining regional priorities and their budgeting allocation planning. There is a perception of the implementation in the regions, that there is no difference in mechanisms for programming and 


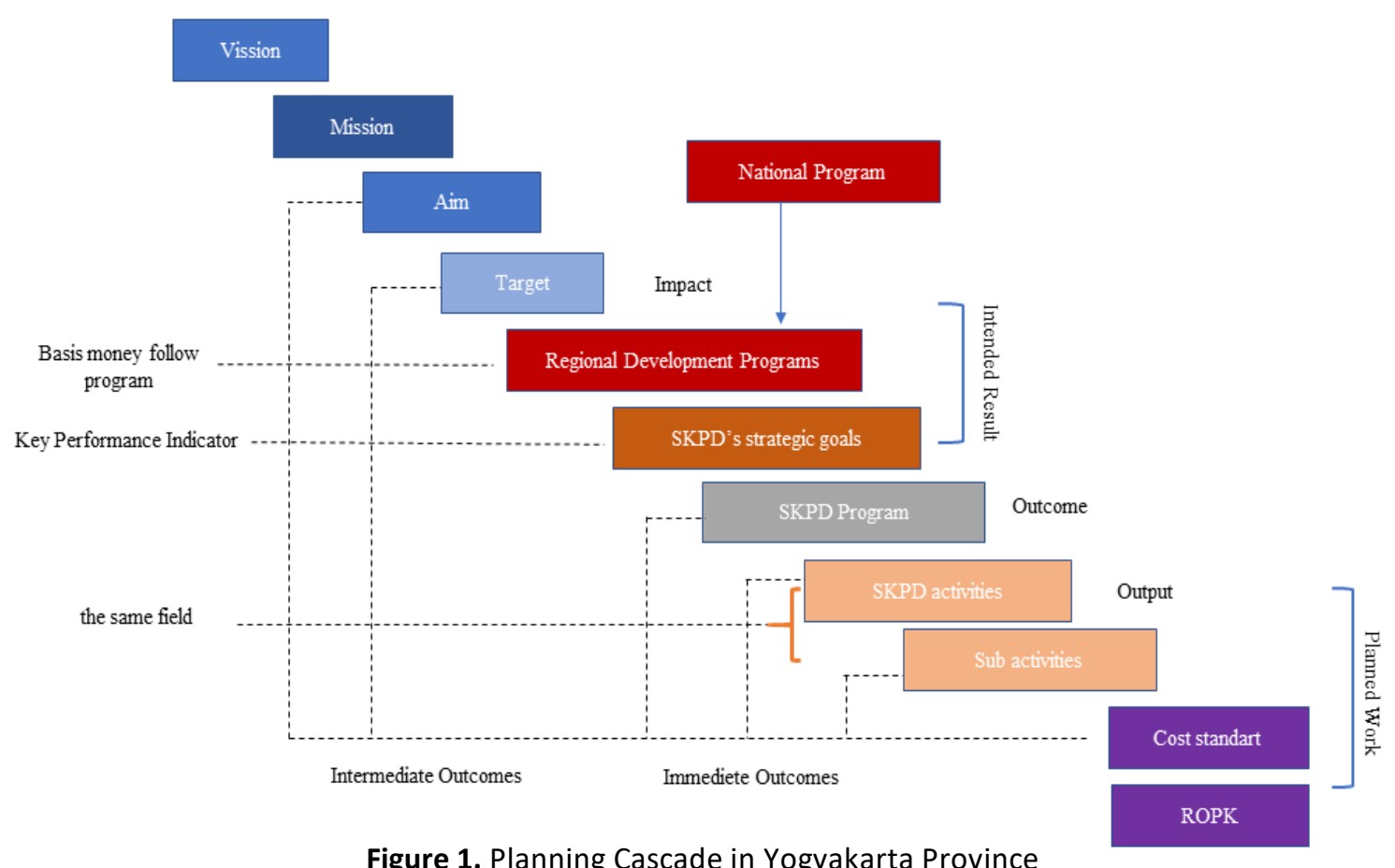

Figure 1. Planning Cascade in Yogyakarta Province Source: (Sengguh DIY, 2019)

activities using the money follow program approach. This is because since the money follows function approach applied, the regions have also set regional priorities, so there need to be guidelines regarding the mechanism for programming and activities using the money follow program approach. Not only guidelines but socialization are also needed so that they can be in line with the same perception.

\section{Human Resources}

Resources can be a supporting factor, but on the other hand, it can be a limiting factor (Ipsen, Gish, \& Poulsen, 2015). The lack of human resources in West Sumatra Province, both implementing and planning human resources, is a factor that hinders the implementation of both planning and implementation of priority programs. In Yogyakarta Province, human resources support is very good, especially in terms of quality. Human resources understanding in implementing the money follow program is quite good.

Changing the human resources mindset is not easy, especially changing the mindset of implementing OPDs that do not carry out priority programs. However, the money follows program policy is still very common in OPD (Katho, 2020; Nugroho, 2013), it is necessary to improve the quality of human resources in understanding the principles of the money follow program. For OPDs that carry out priority programs, it is not only the quality of human resources must be good, the quantity is also needed. This is due to the bigger the budget, the bigger role for the human resources required. However, the number of human resources is still lack in almost all OPDs.

On the other hand, the budget is still an obstacle for West Sumatra Province due to limited budgets for implementing priority programs. In the implementation of programs and activities in West Java Province, 
the budget comes from the local government budget (Anggaran Pendapatan dan Belanja Daerah, APBD) and state budget (Anggaran Pendapatan dan Belanja Negara, APBN). However, this is still not sufficient, so the West Java Provincial Government also collaborates with the private sector in supporting the implementation of regional priority programs. The availability of a budget to support the implementation of programs and activities (money follow program) in West Java is greatly helped by sharing funding through both the government and the private sector, especially for strategic programs/ activities at the national and international levels.

\section{Policy Substance}

The policy substance which is quite easy to understand also supports implementation. The preparation of programs and activities based on the principle of the money follow program will be more effective and efficient as it emphasizes regional priority programs. This makes it easier for the regions to determine the activities to be implemented so that programs and activities.

The preparation of activities in Yogyakarta Province is based on the previously arranged cascading to ease the preparation of activities. According to the three loci of study, the principle of the money follows program is easier to understand and can produce clear and concrete programs as well as efficient and effective. By using the money follow program principle where development priorities have been set, it will facilitate the preparation of development planning and budgeting.

\section{Implementing Behavior}

Strong commitment from all parties is needed to support policy implementation (Dietz, Dan, \& Shwom, 2007). All stakeholders (Governor, DPRD/Regional House of Repre- sentatives, and OPD) in West Sumatra, West Java, and Yogyakarta Provinces are committed to implementing the money follow program policy. Support from the regional head is needed because priority programs are a reflection of the governor's vision and mission. Besides, there also a need for support from the DPRD because planning and budgeting cannot be separated from the role of the DPRD. Likewise with the commitment from the OPD, because the OPD will carry out the activities. The commitment from the OPD is needed for the programs and activities that have been planned can be felt optimally by the community. In its implementation, all parties have been involved in planning (holistic-integrative-thematic-spatial), which is more participatory. The full commitment of the governor will give impact/ change to OPD. The commitment of Yogyakarta's governor is very good, and the implementation of the money follow program principle is a direction from the governor, as well as the commitment from DPRD and OPD.

\section{Network Interaction}

Coordination between regional heads and DPRD also between OPDs in West Sumatra and West Java is very good because they understand each other's duties and functions (Esariti, Haulah, \& Sunarti, 2019). This is one of the positive values that support the implementation of the money follows program. The implementation of programs and activities is not only carried out by one OPD, but it is also possible for one program to be carried out by several DPOs, so that good coordination is needed so that the program can run well and development targets can be achieved. One of the advantages of Yogyakarta is that the governor is not elected politically so that support for the political atmosphere is positive. Positive working relationships are created through good coordination between the governor and officials. All par- 
ties have been involved in planning (holisticintegrative-thematic-spatial), are more participatory, and full of commitment from the governor.

\section{CONCLUSION}

Planning programs and activities in West Sumatra, West Java, and Yogyakarta Provinces have used the money follow program approach. However, the implementation is still different depending on the perception of each region in understanding it. In addition, there are still doubts from the regions in implementing it, because there is no legal basis yet. This program can only be seen in planning documents such as the RPJMD, RKPD, and Strategic Plans (Rencana Strategis, Renstra) of each OPD.

Furthermore, it is necessary to make adjustments to the policies of the Minister of Home Affairs related to guidelines for regional development planning and budget allocation. The government needs to consider the need for special rules regarding stages, procedures for formulating, controlling, and evaluating the implementation of regional development plans. Concretely, the central government also needs to encourage the completion of regulatory revisions related to the balance of central and regional finances, one of which is the substance of regulations related to the administration of money following a function -based budgeting system. Besides, it is needed to encourage ministries/agencies to make adjustments to regulations regarding norms, standards, procedures, and criteria to accommodate the money follow program in the planning and budgeting aspects of related ministries/agencies. On the other hand, the central government needs to issue guidelines for the implementation of planning and budgeting using the money follow program approach. Institutions such as Bappenas also need to conduct regular socialization related to planning and budgeting using the money follow program approach. Finally, it is necessary to hold training for human resource planners in the regions related to planning and budgeting arrangements using the mo-ney follow program approach.

\section{REFERENCES}

Alwasilah, A. C. (2003). Pokoknya kualitatif: Dasar-dasar merancang dan melakukan penelitian kualitatif. Jakarta: Pustaka Jaya.

Analisis kebijakan "money follow function" menjadi "money follow program". (2019). Retrieved from https:// www.bastamanography.id/analisiskebijakan-money-follow-functionmenjadi-money-follow-program/

Bappenas. (2009). Pedoman restrukturisasi program dan kegiatan. Jakarta: Bappenas.

Bappenas. (2016). Kebijakan Bappenas dalam mewujudkan sinergitas perencanaan pembangunan nasional dan daerah. Retrieved from https:// docplayer.info/32521865-Kebijakanbappenas-dalam-mewujudkansinergitas-perencanaan-pembangunan -nasional-dan-daerah.html

Deda, A., Karamoy, H., \& Gamaliel, H. (2017). Pengaruh prosedur reviu, kompetensi, dan jangka waktu pelaksanaan terhadap kualiats reviu laporan keuangan pemerintah daerah pada Inspektorat seProvinsi Gorontalo. Jurnal Riset Akuntansi dan Auditing "Goodwill," 8 (1), 222-232. DOI: 10.35800/ jjs.v8i1.15426

Dietz, T., Dan, A., \& Shwom, R. (2007). Support for climate change policy: Social psychological and social structural influences. Rural Sociology, 72(2), 185214. DOI: 10.1526/003601107781170026

Esariti, L., Haulah, L., \& Sunarti, S. (2019). Pengarusutamaan gender dalam program gerbang hebat sebagai strategi pengentasan kemiskinan di Kota Semarang. Tataloka, 21(1), 140-152. DOI: 10.14710/tataloka.21.1.140-152

Haliim, W. (2020). Problematika kebijakan 
dana hibah dan bantuan sosial sumber APBD: Relasi korupsi terhadap kekuasaan kepemimpinan, dan perilaku elit. Inovasi, 17(1), 39-53. DOI: 10.33626/inovasi.v17i1.136

Himawan, A. (2017, January 31). Jokowi larang kebijakan money follow function. Suara.com. Retrieved from https://www.suara.com/bisnis/2017/ 01/31/150057/jokowi-larang-

kebijakan-money-follow-function

Ipsen, C., Gish, L., \& Poulsen, S. (2015). Organizational-level interventions in small and medium-sized enterprises: Enabling and inhibiting factors in the PoWRS program. Safety Science, 71 (C), 264-274. DOI: 10.1016/ j.ssci.2014.07.017

Katho, D. M. (2020). Analisis konsistensi antara dokumen perencanaan dengan anggaran pendapatan dan belanja daerah (Studi pada Pemerintah Kabupaten Belu tahun 2009-2014). Accounting and Business Information Systems Journal, 4 (3), 1-17. Retrieved from https:// journal.ugm.ac.id/abis/article/ view/59328

Kusuma, H. (2016, February 10). Presiden Jokowi: Anggaran itu harus money follow program. Okezone.com. Retrieved from https:// economy.okezone.com/read/2016/ 02/10/20/1308903/presiden-jokowi -anggaran-itu-harus-money-followprogram

Lestari, S. E., Suryono, A., \& Domai, T. (2018). Implementasi kebijakan pengembangan Kawasan Strategis Cepat Tumbuh (KSCT) di Kabupaten Pacitan. Journal of Public Sector Innovations, 2(1), 10-16. DOI: 10.26740/jpsi.v2n1.p10-16

Matondang, N. I., Basri, H., \& Arfan, M. (2015). Pengaruh sinkronisasi perencanaan dan penganggaran, partisipasi anggaran dan kejelasan sasaran anggaran terhadap kinerja SKPD pada Pemerintah Kabupaten Aceh Utara. Jurnal Administrasi Akuntansi: Program Pascasarjana Unsyiah, 4(4), 36-45. Retrieved from http://www.jurnal.unsyiah. ac.id/JAA/article/view/4487

Ningsih, S., Wirahadi, A. A., \& Fontanella, A.
(2018). Analisis penerapan anggaran berbasis kinerja dengan konsep money follow program dalam perencanaan dan penganggaran Kota Padang. Jurnal Akuntansi dan Manajemen, 13(1), 1-16. DOI: 10.30630/ jakmenpnp.13.1.119

Nugroho, Y. S. (2013). Analisis sumber dan penggunaan pendapatan daerah pada Kabupaten Minahasa Selatan periode 2010-2012. Jurnal Riset Ekonomi, Manajemen, Bisnis dan Akuntansi, 1 (4), 886-894. DOI: 10.35794/ emba.v1i4.2825

Pranata, A., Irianto, G., \& Adib, N. (2018). Anggaran pemerintah daerah dalam bingkai amin, aman, uman: Sebuah studi Semiotika Barthesian. Journal Akuntansi Aktual, 5(1), 76-91. Retrieved from http:// journal2.um.ac.id/index.php/jaa/ article/download/2690/1648

Law of The Republic of Indonesia Number 17 of 2003 concerning State Finance (Undang-Undang Republik Indonesia Indonesia Nomor 17 Tahun 2003 tentang Keuangan Negara). Retrieved from https://www.hukumonline. com/pusatdata/detail/17183/ undangundang-nomor-17-tahun2003

Law of The Republic of Indonesia Number 25 of 2004 concerning National Development Planning System (Undang -Undang Republik Indonesia Indonesia Nomor 25 Tahun 2004 tentang Sistem Perencanaan Pembangunan Nasional). Retrieved from https:// www.hukumonline.com/pusatdata/ detail/19784/node/537/uu-no-25tahun-2004-sistem-perencanaanpembangunan-nasional\#

Law of The Republic of Indonesia Number 23 of 2014 concerning Local Government (Undang-Undang Nomor 23 Tahun 2014 tentang Pemerintah Daerah). Retrieved from https:// peraturan.bpk.go.id/Home/ Details/38685/uu-no-23-tahun-2014

Rosita, A. (2017). Komitmen Bappeda pada kegiatan Musrenbang RKPD dalam meningkatkan efektivitas kerja SKPD pada Program RPJMD di Kabupaten Ciamis. Journal of Management Review, 1(2), 87-96. DOI: 10.25157/ jmr.v1i2.703 
Saputri, S. N. (2019). Prinsip money follow program dalam perencanaan anggaran pendapatan dan belanja daerah berbasis kinerja di Provinsi Lampung. Retrieved from Digital Repository Unila. (55930/2).

Sengguh DIY. (2019). Cascade Pemerintah Daerah Daerah Istimewa Yogyakarta. Retrieved from https:// sengguh.jogjaprov.go.id/s2020/ cascade/index? MENU_ID=asdassygsf\&

Suharnoko, D. (2019). Efektivitas penerapan anggaran berbasis kinerja terhadap kinerja perangkat daerah di Kabupaten Malang. Karta Rahardja Jurnal Pembangunan dan Inovasi, 1(2), 113. Retrieved from http://ejurnal.malangkab.go.id/index.php/kr/article/ view/25

Wasono, A., \& Maulana, M. (2018). Tinjauan kritis perencanaan dan penganggaran pembangunan di Indonesia. Knowledge Sector Initiative, 27. Retrieved from https://www.ksiindonesia.org/assets/uploads/ original $/ 2020 / 03 / \mathrm{ksi}-$ 1585487219.pdf

Zarista, E., \& Ichsan, M. (2020). The roles of political power in budget process: How to accomodate them? A case study. Jurnal Tata Kelola dan Akuntabilitas Keuangan Negara, 6(1), 87 -102. DOI: 10.28986/jtaken.v6i1.412 


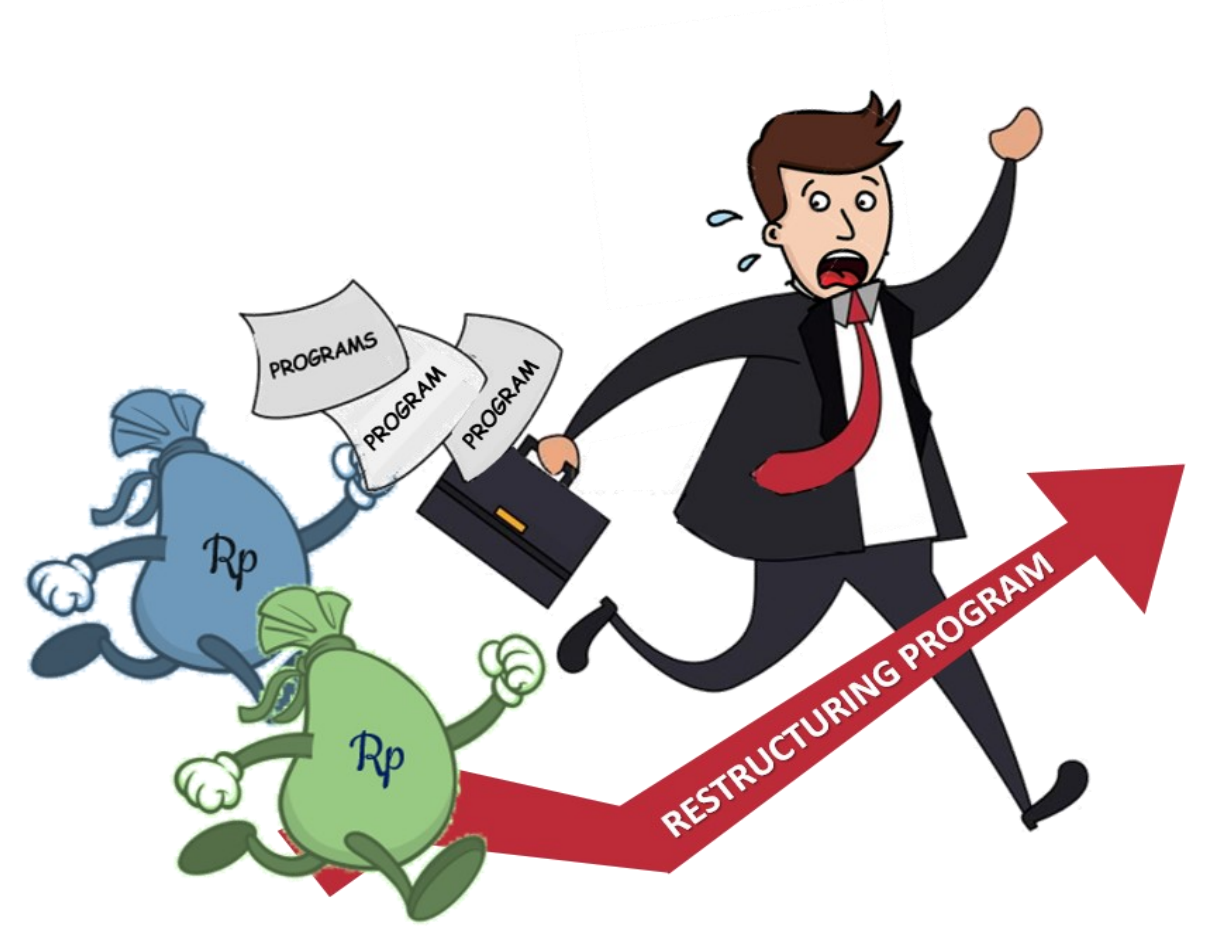

